\title{
Analysis of the Effect of Service Quality on Satisfaction of Visitors of Blitar Agrotourism Using Servqual
}

\author{
Dinu Saadillah ${ }^{1}$, and Bambang Syairudin ${ }^{1}$
}

\begin{abstract}
Blitar kakao agro tourism object is a combination of tourism and cocoa fruit plantations combined into agroeducational tourism to become a destination that is not only interesting to visit but also provides educational values for visitors, especially related to cocoa fruit. In addition, tourism managers must also be able to create satisfaction with visitors, one of which is by providing the best service. Therefore, this study was conducted with the aim to determine the effect of service quality on visitor satisfaction of Blitar kakao agrotourism. Service quality includes latent tangible variables, responsiveness, assurance, empathy, and reliability obtained by standardized regression weights which shows an estimate value for the effect of ServQual variables on visitor satisfaction of 0.88 , while the results of regression weights get the value of S.E. amounting to 0.128, C.R. 9,261. Besides that, it can also be seen that the value of $p$ value for the relationship between service quality (ServQual) and visitor satisfaction $<0.05$ so that it can be concluded that service quality has a significant effect on visitor satisfaction. From the structural method it can also be known which indicators have the most influence on service quality where based on the results of the analysis it is found that the reliability dimension has the most influence from the other four dimensions of service quality. This research model can be said to be feasible and acceptable because it has a GFI value of 0.9, TLI of 0.96 and CFI of 0.98 .
\end{abstract}

Keywords-Agro Tourism, Service Quality, Visitor Satisfaction, ServQual.

\section{INTRODUCTION ${ }^{1}$}

Nowadays, Blitar city government has set four priorities for implementation of Blitar city development until 2028 in which one of its priorities the development is agro-tourism.

Interest agro-tourism development is to strengthen the economy and increase the income of Blitar local communities. This is done by improving the quality, quantity, and the added value of a commodity. The agrotourism development priorities have been set forth in the Spatial Plan (RTRW) Blitar Year 2008 to 2028 who were in the process of their establishment as a local regulation (Perda).

\footnotetext{
${ }^{1}$ Dinu Saadillah and Bambang Syairudin are with the Department of Management Technology, Institut Teknologi Sepuluh Nopember, Surabaya, 60111, Indonesia. E-mail: dinusaadillah01@gmail.com; bambangsy@ie.its.ac.id.
}

According [1], there are four important dimensions in the implementation and development of tourism is an attraction, facilities, transportation, and hospitality.

Marketing in tourism involves many things such as the development of services, place (location and distribution), and price. In addition, the marketing in the run optimally it is necessary also knowledge of what is favored by the market. This can be done by appropriately matching between services with a market.

There are three concepts of tourism marketing that should be developed that are design a service to meet the needs and desires of customers, focus on the desire of certain people from the desire of the entire mass market, and develop marketing efforts that are fit for purpose.

The right marketing strategy can make tourism locations always visited by tourists because of marketing strategies can be used to attract the number of tourists, especially for the new travelers who do not know about the existence tourism has been built. As for the tourist who have visited, travel managers must maintain them by providing appropriate services and conduct an ongoing relationship between a manager with tourists.

Attempts to create a unique and attractive tourism is a challenge for the tourism business given the number of local and foreign tourists who visit the many sights of nature that exist in Indonesia. Moreover, entrepreneurs in tourism are also required to develop creative and innovative efforts in accordance with the advantages. One was on the agro sector where ecotourism is an activity that involves the use of agricultural land or related facilities are the main attraction for tourists. Various things developed in the agro sector includes fruit picking tour, labyrinth made of various crops, feed livestock, the restaurant on the water, and others.

In addition, marine travel and cultural tourism, plantation-based tourism is now beginning to be developed in various regions in Indonesia. One of them agrotourism in Blitar which includes starfruit agro, citrus agro, cocoa agro, sirah kencong tea gardens, coffee plantations, agro melon, and others.

But of all the agro developed in Blitar, cocoa agro become tourist destinations most visited plantations. This tourist spot not only offers a variety of preparations made from cocoa but also to educate visitors about the history of the cocoa plant to the process of planting and maintenance 
and into refined products that have a sale value. Structuring location and a variety of entertainment is also a better value when compared with other agro.

Processed cocoa products have started to be produced starting in 2013 ranging from processed cocoa powder to the other. Another advantage offered by agro cocoa is not only a tourist spot offering tours on farm but also travel off the farm. It makes agrotourism cocoa plantations became a tourist destination most visited compared to other agro.

Customer satisfaction also affect the sustainability of agro-tourism. Customer satisfaction can be done by providing a good service in various sectors such as transportation, tours and hotels, restaurants, and others. All sectors must work together with one another. If one party fails to provide the service as expected by the consumers it will impact on the satisfaction of every customer. Therefore, every agrotourism in Blitar must observe and perform continuous improvement in the quality of service. To achieve this, a proper assessment of the existing condition of service quality. From these values, every agrotourism in Blitar be able to know with certainty the priority that is used to develop the service.

Quality of service is said to be good if the value of service can exceed expectations so that the manager of agro users must know what they want visitors. Visitors will feel satisfied if management provides a good service. Furthermore, the value of the service quality to be used as a benchmark evaluation material to improve the quality of service.

Based on the description that has been described above, the objectives to be achieved in this study was to determine the effect of service quality dimensions that include tangibles, reliability, responsiveness, assurance, and empathy to visitor satisfaction. and find out how much of tangibles, reliability, responsiveness, assurance, and empathy simultaneously contributes to visitor satisfaction.

\section{LITERATURE REVIEW}

\section{A. Quality of Service}

Kotler[2] defines a service as any action or activity that can be offered by one party to another, which is essentially intangible and does not result in any ownership. Production may be linked or not linked to a physical product. Service is the behavior of producers in order to meet consumer needs and desires in order to achieve customer satisfaction in itself. Kotler also said that the behavior also occurs at the time, before and after the transaction. In general, a high standard of service will generate high satisfaction and the more frequent transactions.

Swastha[3], stating that the service is defined as the direct activities in obtaining and using goods or services, including the decision making process.

While the quality is defined as meet the needs of businesses that include products, services, people and the environment so that the quality is said to be good if service providers are able to serve in accordance with customer expectations. Vice versa the quality of service is said to be worse if the customer does not receive services in accordance with their expectations.

Mardiyatmo[4] suggests that there are some guidelines to be able to give satisfaction to customers among others include: understanding customer expectations, choosing the right customers through segmentation strategy then wake of customer satisfaction, to study the factors that affect customer satisfaction, making customers become more loyal, giving guarantees to customers, listen to complaints or wishes of customers, hang on employees to give satisfaction to the customers.

Some factors that could affect customer satisfaction include:

\section{1) Product quality}

The product can be said to be good quality if a buyer is satisfied when using the product because of its quality as convenience in using the product, high durability, safety and good design.

\section{2) Price}

Customers will be satisfied if the purchased product quality and supported at an affordable price.

\section{3) Service quality}

Quality of service is one of the company's main priorities due to the satisfaction of the quality of service is difficult to imitate, so it can be a distinct advantage for an enterprise

\section{4) Emotional factors}

Emotional factors referred to is a sense of pride, self confidence when customers use a product.

\section{5) Easy service}

Customers will be more satisfied when customers receive a service that is easy, convenient, avoiding long queues and efficient.

\section{B. Dimensions of Service Quality}

Zeithaml[5], states that there are five dimensions used in measuring the quality of services, namely: tangible in the form of appearance of physical facilities, equipment, employees, and material. In addition, tangible also describes the physical form such as state building, restaurant facilities, restaurant design, and employee neat appearance.

Reliability can be interpreted as the accuracy in delivering the promised services. For example the company is said to be reliable if an employee is able to provide services as promised and were able to help solve the problems faced by consumers quickly.

In addition, the company should also be able to deliver its services correctly and is able to fulfill his promise to accurately and reliably in accordance with what has been agreed. The company also must submit the data properly and is able to send the bill accurately.

Responsiveness is the willingness of providers to help consumers and provide services quickly. It can be seen 
from the ability of employees in give the service to consumers quickly and can handle complaints quickly as well.

Assurance is the knowledge, courtesy, and the employee's ability to convince and give confidence to consumers. Provide certainty such as security, safety in the transaction, ensuring privacy is an important thing that should be given to the consumer. The Company is said to provide a guarantee if employees can be polite at all times, have the skills to handle any customer problems, have a good knowledge about the products or services offered, polite and trustworthy so that customers feel safe and secure.

Empathy can be defined as the level of care and personal attention given to the customers. Caring attitude to the consumer must be provided by the employees so that consumers can be satisfied with the services provided. The company is said to have high empathy if they are able to understand the wishes of the customer, the customer may notice a feeling and attention to the availability. Ease in relationships, good communication, personal attention and understand the needs of consumers must also be owned by a service provider.

Parasuraman[6] also undertake the preparation of a basic dimension that becomes the determining factor for the quality of services which include:

1. Reliability: the ability to realize the promised service reliably and accurately.

2. Responsiveness: willingness to help consumers by providing a fast and accurate service.

3. Assurance include: knowledge, skills, and decency or goodness of personal as well as the ability to gain the confidence and desire.

4. Empathy includes maintain and provide the level of individual or personal attention to the needs of consumers.

5. Tangible include physical facilities, equipment or supplies, prices, personal appearances and written material.

\section{Measuring Customer Satisfaction}

Tjiptono[7], states that there are several methods for measuring satisfaction, namely:

\section{1) Complaints and Feedback}

Opportunity to submit suggestions, comments, opinions and complaints need to be given to the customer for customer oriented to service provider. This is done to accommodate the complaint, for example a suggestion box that is easily accessible or frequently skipped customer comment card, or a phone line.

From this information will be obtained by new ideas and valuable feedback to the company, so that the problems that arise can be solved quickly. But this method is passive so that an image of the customer's satisfaction or dissatisfaction difficult to obtain.
There might be some customers who instantly switch to another without submit complaints for unsatisfactory services, so it is not easy to get good suggestions from customers when using this method. Especially if the company did not provide feedback or follow up to the customers who have bothered to contribute ideas.

\section{2) Ghost Shopping}

Employing some people (Ghost Shopper) is one way to gain an overview of customer satisfaction that they contributed to or behave as potential customers for the company's own as well as competitors. The next ghost shopper can also provide information to others about the strengths and weaknesses of the company's products and competitors based on their experience.

In addition, the Ghost Shopper can also observe how the company and its competitors in serving the demand of customers, answer customer questions, as well as in dealing with customer complaints. The manager can also be a Ghost Shopper so they can find out directly how employees interact and treat customers with the requirements of employees do not know if his boss is doing research or assessment.

\section{3) Lost Customer Analysis}

Contacting customers who have stopped buying or who have switched to other service providers need to be done by the company in order to understand why it happens. One of the things that can be done by the company is a lost customer rate so that it can be seen whether the company failed to satisfy the customer or not.

\section{4) Customer Satisfaction Survey}

Research on customer satisfaction is usually done through a survey to customers where the survey can be done by mail, telephone or personal interview. The company will obtain a response or feedback directly from customers through the survey results. In addition the survey results can also give a positive sign to customers that the company pay attention to them. The benefits of the creation of customer satisfaction that is the establishment of a harmonious relationship between companies and customers that would affect the re-purchase and create customer loyalty. Customers also will recommend the company through word of mouth so that it can benefit the company.

\section{Customer Value}

Customer value is an important concept in decision making so that the company has the scale of priorities related to customer satisfaction. Customer value is the difference between total customer value and total customer cost where the total customer value is defined as a set of benefits that are expected by the customers of a particular product or service. While the total customer cost of a set of expected costs incurred by consumers to evaluate, acquire, use and dispose of the product or service.

The goal of customer value is increased customer satisfaction so the right customer value will help the product is better than a competitor's product. 
The quality of customer value can also be used as a reference for monitoring whether the long-term goals, medium, or short accordance with customer wishes.

The benchmarks of customer value is how long the time of the adoption of the expectations and needs of customers. Moreover, the benchmarks of customer value can also be seen from the amount of information that was adopted by companies in building customer value.

Customer satisfaction, quality of service, and customer value is highly related to one another. Quality of service can be measured based on a specific incident or cumulatively. There are three aspects required by the management of service quality that is by designing products services, designing services environment, and deliver quality services. So the customer value not only covers the customer value quality, but also covers the price.

Bids will be accepted by the customer if the company is able to deliver value and satisfaction to the buyer. Buyers will choose among diverse bid is considered to give the most important value.

Kotler suggests that the value can be seen as a combination of quality, service, and price or referred to as the triad of customer value. Value will increase with the quality and services and will decrease with the price although other factors also have an important role in customer value.

\section{MethodOLOGY}

\section{A. Research Instruments}

Research aimed to measure satisfaction on agrotourism services in Blitar, especially kakao agrotourism. The research design used in this satisfaction analysis is descriptive quantitative research where such analysis combines qualitative data with quantitative data. And then data will be used to measure the satisfaction level of service for visitors kakao agrotourism in Blitar.

The research instrument used was a questionnaire in the form of the rating scale in accordance with the scale of measurement is used. From these data can also be known indicator of poor quality, the quality indicators that should be improved, as well as indicators of quality is good or indicators that should be maintained.

\section{B. Data Collection and Processing}

The sampling technique is generally divided into two: probability sampling and non-probability sampling. Sampling was based on probability sampling is done by taking a random sample of each unit of the population and have the same opportunity to be taken as a sample so that the sample selection factor is not solely on the consideration of researchers in order to avoid bias. By way of random, selection bias can be made as small as possible. While sampling by way of non-probability sampling to determine the magnitude of the opportunity element of unknown samples.
The samples in this study used a non-probability sampling with convenience sampling method. This technique describes anyone who can provide information either intentional or just happened to meet with researchers, can be used as a sample if people are asked to provide such information is suitable as a data source.

The data collection is done by distributing questionnaires where the questionnaire contained in the level of response should be chosen by the respondent. Criterion levels of answers using a Likert scale of 5 points consisting of:

\section{5: SS or Strongly Agree}

4: $S$ or Disagree

3: $\mathrm{N}$ or Neutral

2: TS or Disagree

1: STS or Strongly Disagree

Questionnaires were made where the interview data taken on the actual conditions and then be tested for validity and reliability levels. Test the validity of the data was conducted in order to determine whether or not valid questionnaires so that the measuring instrument used must have good accuracy and can be known to the data which must be repaired or removed so that all research data becomes invalid. As for the validity of the test steps include:

a. Defining the concept to be measured

b. Measurement scale trials

c. Preparing the table answers

d. Bivariate correlation calculations with the help of SPSS software

Bivariate correlation calculation performed to determine the degree of relatedness between one question with another question. According Sugiyono[8] there is a reference in providing correlation coefficients include:

$$
\begin{aligned}
& 0.00 \text { to } 0.199: \text { Very Low } \\
& 0.20 \text { to } 0.399: \text { Low } \\
& 0.40 \text { to } 0.599 \text { : Medium } \\
& 0.60 \text { to } 0.799 \text { : Strong } \\
& 0.80 \text { to } 1.000 \text { : Very Strong }
\end{aligned}
$$

After the test the validity of the next step is to test the reliability. Reliability is a measure of the level of confidence or reliability levels where if the measuring instrument can be used repeatedly to measure the same thing and was able to show consistent results then the gauge can be said to be reliable. Sugiyono also explained that if the coefficient of Cronbach's Alpha showed values above 0.6 then the measuring instrument can be said to be reliable or reliable.

Basuki[9] explains that if the value of alpha $>0.7$ means that the reliability is sufficient and if the value of alpha> 0.8 then the entire item is reliable and has a strong reliability. There are several references in giving result which include:

If the alpha value $>0.9 \quad$ : reliability perfect

If the alpha value between 0.7-0.9: High reliability 
If the alpha value of $0.5-0.7$

If the alpha value $<0.5$

: Moderate reliability

: Low reliability

Moreover, the questions can also be said to be reliable if the alpha value $r$ is greater than $r$ table and said to be unreliable if the alpha value $r$ is smaller than $r$ table

Processing of primary data collected from the survey respondents using SEM (Structural Equation Models) to determine the relationships between latent variables. In the SEM key variables of concern is the latent variable (Latent Variables) or latent constructs.

Latent variables is an abstract concept, for example: dimensions of service quality and customer satisfaction. These latent variables can be observed only indirectly and imperfectly through its effect on the observed variables. SEM has two kinds of latent variables are exogenous and endogenous.

SEM distinguish these two types of variables based on their participation in dependent variable of equations in the model. Exogenous variables always appear as independent variables in all the equations in the model.

While endogenous variable is the dependent variable in at least one equation in the model, although in all the equations remaining variable is the independent variable.

Structural model describes the relationships that exist between latent variables. These relationships are generally linear, although expansion of SEM make it possible at nonlinear relationship.

Each latent variable usually have some size or unobserved variables or indicators. SEM users most often connects latent variable to the variables observed through measurement model in the form of the factor analysis and are widely used in psychometric and sociometry. In this model, each latent variable is modeled as a factor underlying the observed variables are related. "The loads factor" or "loading factor" that connects the latent variables to variables observed

\section{Research Variables}

The research variables are all things that any form defined by the researchers to be studied in order to obtain information about it, then drawn conclusions. The variables in this research are:

\section{1) Latent Variables}

Is a variable that can not be measured directly but can only be measured by one or more manifest variables. This variable is also referred to as unobserved variables. In this study, each of endogenous and exogenous variables are latent variables, namely $\mathrm{T}, \mathrm{A}, \mathrm{Rs}, \mathrm{Rl}, \mathrm{E}$, and visitor satisfaction.

\section{2) Variable of Manifest}

While the manifest variable, is a variable that can be measured directly and measure latent variables. This variable is called observed variables. In this study, each indicator explain the endogenous and exogenous variable which is an indicator of T1, T2, T3, T4, T5, T6, T7, T8, E1, E2, E3, E4, Rs1, RS2, RS3, RS4, RL1, RL2, Rl3, Rl4,
Rl5, KP1, KP2, KP3, KP4, Kp5, Kp5, Kp7, Kp8, A1, A2, A3, A4

\section{3) Exogenous Variables}

Exogenous or often also known as the independent variable, is a variable that is not influenced by other variables and affect the dependent variable. In the SEM, the variable is indicated by the arrows coming from these variables to the endogenous variables. In the present study that included this variable is ServQual.

\section{4) Endogenous Variables}

Endogenous variable or often also known as the dependent variable, is a variable that is affected by the independent variable (exogenous). In the SEM, the variable is indicated by the arrows towards this variable. In the present study that included these variable is visitor satisfaction.

\section{RESULT AND DISCUSSION}

\section{A. Confirmatory Factor Analysis (CFA)}

This study used five latent variables used in measuring visitor satisfaction that are tangible, responsiveness, assurance, empathy, and reliability which each latent variable measured by indicators.

Before performing confirmatory factor analysis, then the assumption that must be met is to test whether the data were normally distributed or not. Normality test is done by using a scatter-Polt and the correlation between the mahalanobis with chi square. The hypothesis is:

$\mathrm{H}_{0}$ : Data derived from normally distributed population

$\mathrm{H}_{1}$ : Data from the population is not normal

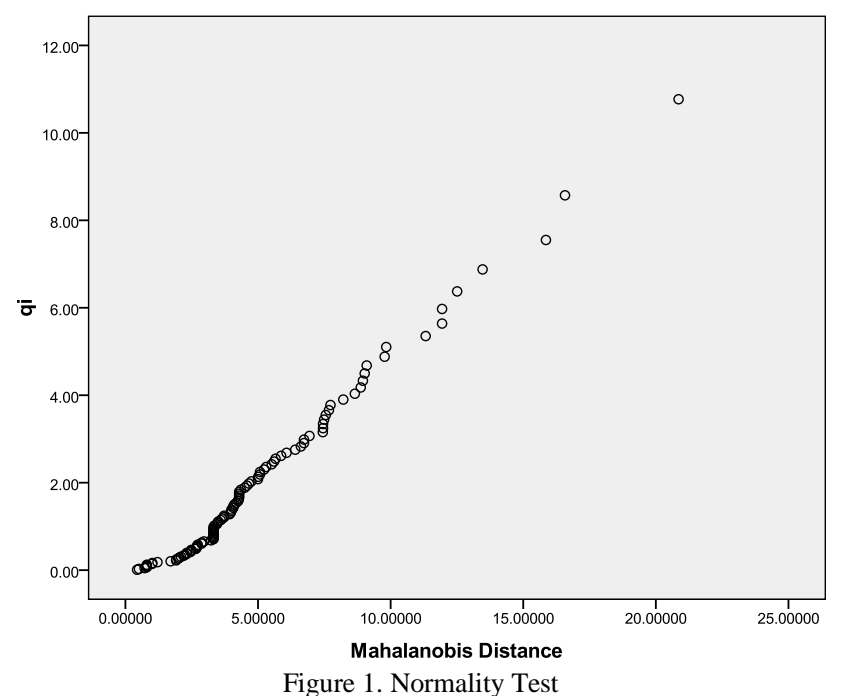

Based on the results of analysis show that visually $50 \%$ plot forming a linear line and based on bivariate correlation analysis obtained sig $0.000<0.05$ so that it can be concluded that the data derived from normally distributed population. 
After being tested for normality then the next step is to test the unidimentionality of tangible, responsiveness, assurance, empathy, and reliability latent variable.

\section{B. Unidimentionality Test for Tangible Latent Variables}

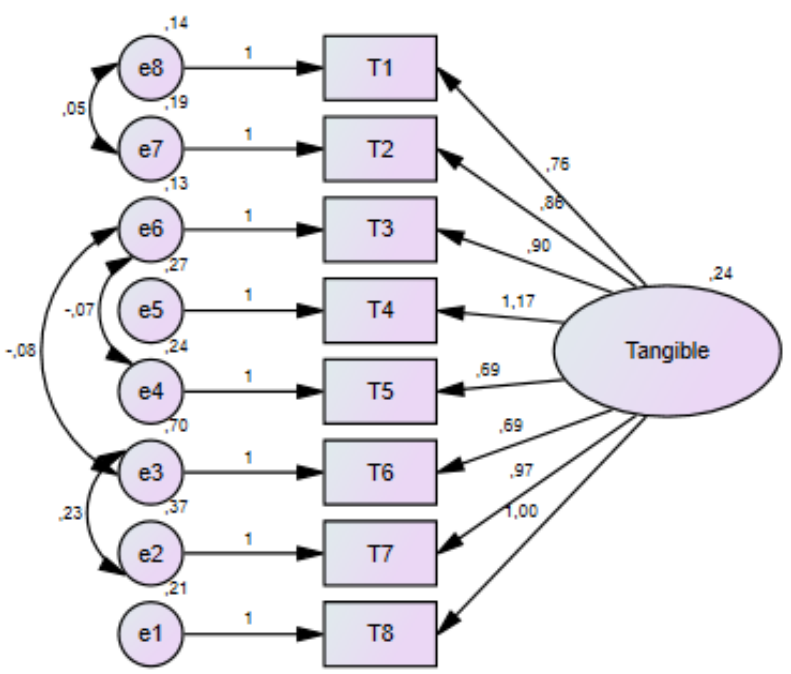

Figure 2. Confirmatory Factor Analysis Model for Tangible Variable

From the picture above shows that the goodness of fit value indicates that the criteria RMSEA has shown marginal fit criteria (0.83). Furthermore, the value of GFI showed good fit criteria (0.93) and AGFI currently on the criteria of marginal fit (0.86). While the value of TLI produce good fit criteria (0.94) and CFI showed good fit criteria (0.96) as well. It can be concluded that the model already looks good in describing the data and the actual conditions so that it can be said model has been accepted.

TABLE 1.

LOADING FACTOR AND CONTRIBUTION VALUE OF TANGIBLE VARIABLE

\begin{tabular}{ccccc}
\hline \hline & \multicolumn{2}{c}{ Before Modification } & \multicolumn{2}{c}{ After Modification } \\
\cline { 2 - 5 } & Estimate & $\mathbf{R}^{2}$ & Estimate & $\mathbf{R}^{2}$ \\
\hline $\mathrm{T}_{1} \leftarrow$ - Tangible & 0,75 & 0,56 & 0,71 & 0,5 \\
$\mathrm{~T}_{2} \leftarrow$ - Tangible & 0,76 & 0,56 & 0,7 & 0,48 \\
$\mathrm{~T}_{3} \leftarrow$ - Tangible & 0,72 & 0,51 & 0,78 & 0,61 \\
$\mathrm{~T}_{4} \leftarrow$ - Tangible & 0,71 & 0,50 & 0,75 & 0,56 \\
$\mathrm{~T}_{5} \leftarrow$ - Tangible & 0,53 & 0,28 & 0,57 & 0,33 \\
$\mathrm{~T}_{6} \leftarrow$ - Tangible & 0,41 & 0,17 & 0,38 & 0,14 \\
$\mathrm{~T}_{7} \leftarrow$ - Tangible & 0,68 & 0,46 & 0,62 & 0,39 \\
$\mathrm{~T}_{8} \leftarrow$ - Tangible & 0,73 & 0,54 & 0,73 & 0,54 \\
\hline \hline
\end{tabular}

Loading factor of the analytical results indicate that the largest contribution of T3 by 61\% where T3 associated with supporting facilities agrotourism has good naturebased activities (cultivation education, maintenance, harvesting, and production).
C. Unidimentionality Test for Assurance Latent Variables

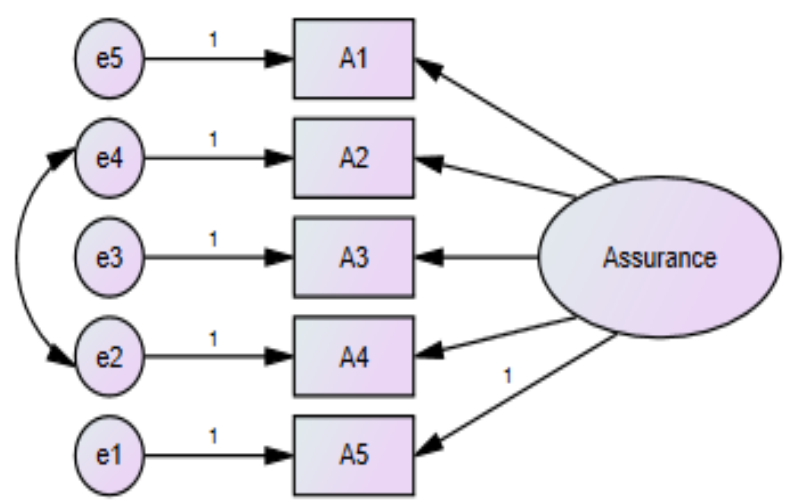

Figure 3. Model Confirmatory Factor Analysis for Assurance Variable

From the picture above shows that the value of goodness of fit, explaining that RMSEA criteria already demonstrated excellent criterion. Furthermore, the value of GFI showed good fit criteria (0.99) and AGFI currently on the criteria of a good fit (0.97). While the value of TLI produce good fit criteria (1.02) and CFI showed good fit criteria as well (1.00). It can be concluded that the model already looks good in describing the data and the actual conditions so that it can be said model has been accepted.

TABLE 2.

LOADING FACTOR AND CONTRIBUTION VALUE OF ASSURANCE VARIABLE

\begin{tabular}{ccccc}
\hline \hline & \multicolumn{2}{c}{ Before Modification } & \multicolumn{2}{c}{ After Modification } \\
\cline { 2 - 5 } & Estimate & $\mathbf{R}^{\mathbf{2}}$ & Estimate & $\mathbf{R}^{\mathbf{2}}$ \\
\hline $\mathrm{A}_{1}<---$ Assurance & 0,65 & 0,42 & 0,64 & 0,41 \\
$\mathrm{~A}_{2}<--$ Assurance & 0,55 & 0,3 & 0,62 & 0,39 \\
$\mathrm{~A}_{3}<--$ Assurance & 0,8 & 0,65 & 0,78 & 0,61 \\
$\mathrm{~A}_{4}<---$ Assurance & 0,84 & 0,7 & 0,87 & 0,76 \\
$\mathrm{~A}_{5}<---$ Assurance & 0,76 & 0,58 & 0,75 & 0,56 \\
\hline \hline
\end{tabular}

Loading factor of the analytical results indicate that the largest contribution of A4 by $76 \%$ which relate to the ability to instill confidence to visitors.

D. Unidimentionality Test for Reliability Latent Variables

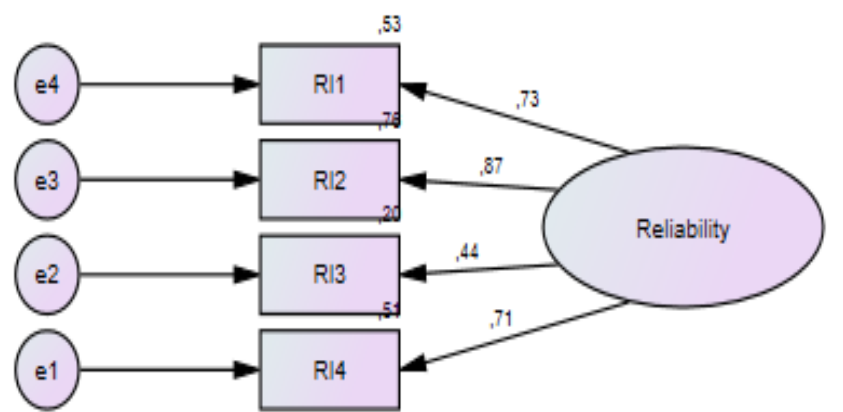

Figure 4. Confirmatory Factor Analysis Model of Reliability Variable 
RMSEA showed a close fit that criteria and GFI is good fit. AGFI (0.99) and TLI (1.04) showed good fit criteria while CFI (1.00) showed good fit criteria as well so that the overall model can be accepted.

TABLE 3.

LOADING FACTOR AND CONTRIBUTION VALUE OF RELIABILITY VARIABLE

\begin{tabular}{lcc}
\hline \hline & Estimate & $\mathbf{R}^{2}$ \\
\hline $\mathrm{Rl}_{1}<---$ Reliability & 0,73 & 0,53 \\
$\mathrm{Rl}_{2}<---$ Reliability & 0,87 & 0,76 \\
$\mathrm{Rl}_{3}<---$ Reliability & 0,44 & 0,20 \\
$\mathrm{Rl}_{4}<---$ Reliability & 0,71 & 0,51 \\
\hline \hline
\end{tabular}

Loading factor of the analytical results indicate that the largest contribution of RL2 which amounted to 76\% where RL2 associated with the ability to provide accurate information.

\section{E. Unidimentionality Test for Empathy Latent Variables}

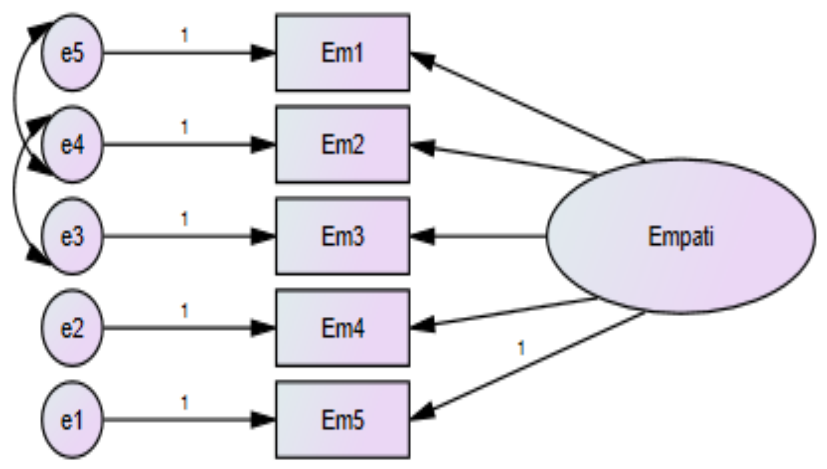

Figure 5. Confirmatory Factor Analysis Model of Empathy Variable

From the picture above shows that the goodness of fit value indicates that the criteria RMSEA showed a close fit criteria and GFI good fit (0.99), AGFI (0.97) and TLI (1.03) showed good fit criteria while CFI (1.00) showed good fit criteria as well so that the overall model can be accepted. The next step is to know the value of the largest contribution to empathy latent variable models.

TABLE 4.

LOADING FACTOR AND CONTRIBUTION VALUE OF EMPATHY VARIABLE

\begin{tabular}{lcccc}
\hline & \multicolumn{2}{c}{ Before Modification } & \multicolumn{2}{c}{ After Modification } \\
\cline { 2 - 5 } & Estimate & $\mathbf{R}^{2}$ & Estimate & $\mathbf{R}^{2}$ \\
\hline Em $_{1}<---$ Empathy & 0,66 & 0,44 & 0,63 & 0,39 \\
Em $_{2}<--$ Empathy & 0,61 & 0,37 & 0,64 & 0,41 \\
Em $_{3}<--$ Empathy & 0,74 & 0,54 & 0,80 & 0,63 \\
Em $_{4}<---$ Empathy & 0,50 & 0,25 & 0,49 & 0,24 \\
Em $_{5}<---$ Empathy & 0,87 & 0,75 & 0,84 & 0,71 \\
\hline \hline
\end{tabular}

Results loading factor analysis shows that the largest contribution to the variable empathy is Em5 which amounted to $71 \%$ associated with the facility where Em5 children play ground safe and comfortable

\section{F. Unidimentionality Test for Responsiveness Latent Variables}

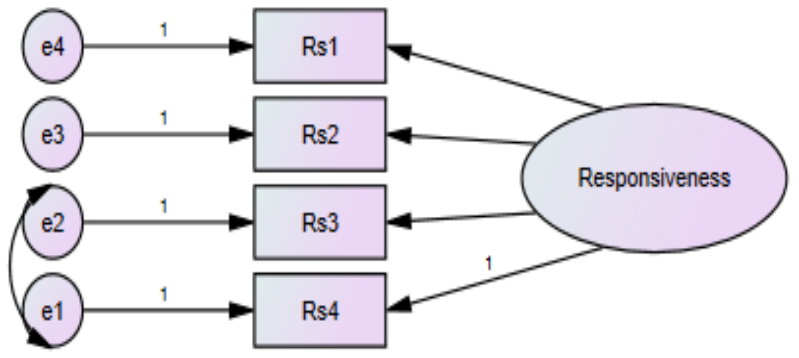

Figure 6. Confirmatory Factor Analysis Model of Responsiveness Variables

From the picture above is known that RMSEA showed a close fit that criteria and GFI good fit (0.99). AGFI (0.97) and TLI (1.01) showed good fit criteria while CFI (1.00) showed good fit criteria as well so that the overall model can be accepted.

TABLE 5. LOADING FACTOR AND CONTRIBUTION VALUE OF RESPONSIVENESS VARIABLE

\begin{tabular}{lcccc}
\hline \hline & \multicolumn{2}{c}{ Before Modification } & \multicolumn{2}{c}{ After Modification } \\
\cline { 2 - 5 } & Estimate & $\mathbf{R}^{2}$ & Estimate & $\mathbf{R}^{2}$ \\
\hline $\mathrm{Rs}_{1}<---$ Responsiveness & 0,73 & 0,53 & 0,71 & 0,50 \\
$\mathrm{Rs}_{2}<---$ Responsiveness & 0,89 & 0,80 & 0,94 & 0,88 \\
$\mathrm{Rs}_{3}<---$ Responsiveness & 0,61 & 0,37 & 0,57 & 0,33 \\
$\mathrm{Rs}_{4}<---$ Responsiveness & 0,50 & 0,25 & 0,45 & 0,20 \\
\hline \hline
\end{tabular}

The next step is to know the value of the largest contribution to latent variable models responsiveness where the largest contribution to variable responsiveness that RS2 which amounted to 88\% where RS2 associated with Blitar kakao agrotourism management having a good responsiveness in dealing with the demand of visitors.

\section{G. Unidimentionality Test for Visitor Satisfaction Latent Variables}

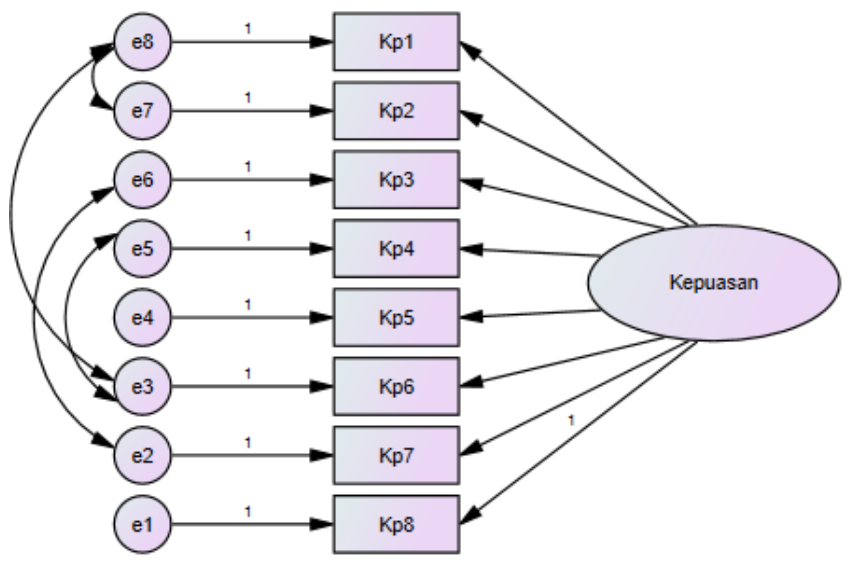

Figure 7. Confirmatory Factor Analysis Model of Satisfaction Variable

Based on the picture above, it is known that the RMSEA showed good fit criteria (0.94) and GFI good fit (0.94). AGFI marginal fit (0.87) and TLI (0.97) showed good fit 
criteria while CFI showed good fit criteria (0.98) as well so that the overall model can be accepted.

The next step is to know the value of the largest contribution to the model latent variables visitor satisfaction where each of the indicators give a different contribution which the largest contribution satisfaction variables that KP4 which amounted to 91\% where KP4 associated with visitors would recommend others to visit Blitar kakao agrotourism.

\section{H. Structural Model Between ServQual Variable and Visitor Satisfaction Variable}

Structural Model is a statistical technique used to build and test the statistical models are usually in the form of causal models. This model is actually a hybrid technique that includes aspects of confirmation (confirmatory) from the factor analysis, path analysis and regression can be considered as a special case.

After the formation of the measurement model using the CFA then the next step is to do analysis of the structural model to determine the relationships between latent variables. In this analysis, the hypotheses to form a structural model. The hypothesis is as follows.

$\mathrm{H}_{1}$ : There is the influence of service quality on visitor satisfaction

$\mathrm{H}_{0}$ : There are currently no influence of service quality on visitor satisfaction

Structural model will be developed based on the hypothesis that shown in the following figure.

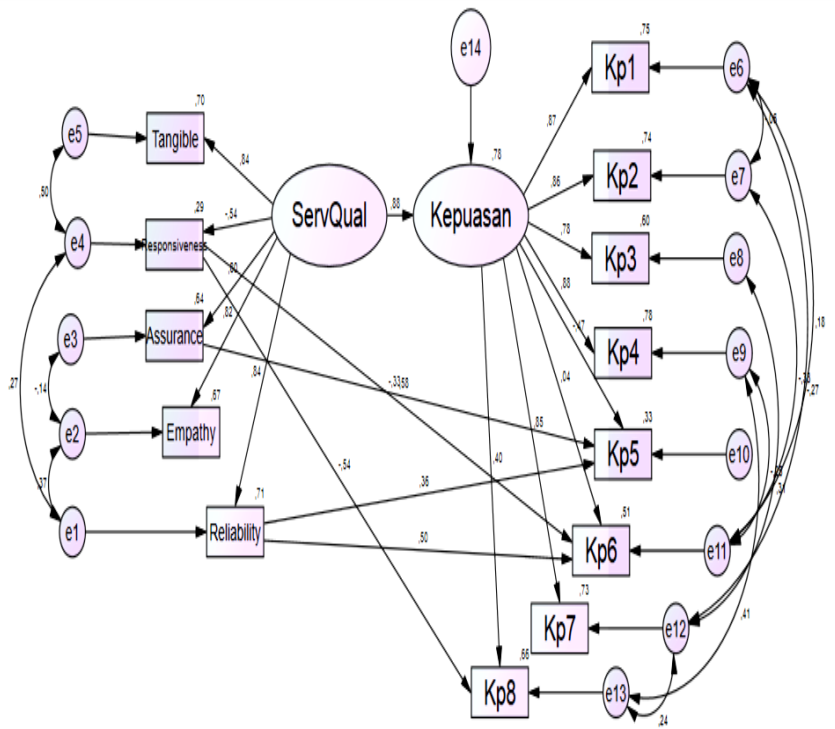

Figure 8. Structural Model Between ServQual Variable and Visitor Satisfaction Variable

Figure VIII shows that service quality directly affects customer satisfaction by 0.88 so that it can be concluded that the higher the quality of services provided will increase visitor satisfaction cocoa agro tourist area of Blitar.
TABLE 6.

GOODNESS OF FIT TEST RESULTS

\begin{tabular}{|c|c|c|c|}
\hline Goodness of Fit & Cut Off Value & $\begin{array}{c}\text { Results } \\
\text { Estimates }\end{array}$ & Information \\
\hline \multirow[t]{2}{*}{$\chi^{2}$ - Chi Square } & - & 76.06 & Small expected \\
\hline & $\leq 0.05=$ Close Fit & & \\
\hline \multirow{4}{*}{$\begin{array}{l}\text { Root Mean Square } \\
\text { Error of } \\
\text { Approximation } \\
\text { (RMSEA) }\end{array}$} & $0.05<$ RMSEA $\leq$ & & \\
\hline & 0,08 = Good Fit & 0076 & Good Fit \\
\hline & $\begin{array}{l}0.08<\text { RMSEA } \leq \\
0.10=\text { Marginal Fit }\end{array}$ & & \\
\hline & $>0,10=$ Poor Fit & & \\
\hline \multirow{3}{*}{$\begin{array}{l}\text { Goodness of } \\
\text { Index (GFI) }\end{array}$} & $\geq 0.90=$ Good Fit & 0.9 & Good Fit \\
\hline & $\begin{array}{l}\text { GFI } \leq 0.80<0.90= \\
\text { Marginal Fit }\end{array}$ & & \\
\hline & $<0,80=$ Poor Fit & & \\
\hline
\end{tabular}

It can be concluded from the above table shows that the model is good because it is based on a model goodness criteria where it is known that RMSEA showed marginal fit and GFI good fit. TLI indicates good fit criteria while CFI show good criteria fit well so overall the model is quite acceptable.

TABLE 7. REGRESSION WEIGHTS

\begin{tabular}{lllllll}
\hline \hline & & & estimate & SE & CR & P \\
\cline { 5 - 7 } Reliability & $\leftarrow$ & ServQual & 1,000 & & & \\
Assurance & $\leftarrow$ & ServQual &, 820 &, 084 & 9.799 & $* * *$ \\
Responsiveness & $\leftarrow$ & ServQual &,- 632 &, 119 & -5.317 & $* * *$ \\
Satisfaction & $\leftarrow$ & ServQual & 1,184 &, 125 & 9.457 & $* * *$ \\
Empathy & $\leftarrow$ & ServQual &, 893 &, 069 & 12.911 & $* * *$ \\
Tangible & $\leftarrow$ & ServQual &, 800 &, 077 & 10.33 & $* * *$ \\
\hline \hline
\end{tabular}

\section{Discussion}

CFA analysis based on tangible dimension value $\mathrm{p}$ value less than 0.05 so it can be said that all significant indicators of tangible latent variables form. In addition, the CFA analysis also shows that the largest contribution to tangible service quality dimensions, namely by $61 \% \mathrm{~T} 3$ where $\mathrm{T} 3$ associated with supporting facilities agrotourism has good nature-based activities (cultivation education, maintenance, harvesting, and production).

While the dimensions of service quality assurance demonstrated A4 provides the largest contribution of 76\% which relate to the ability to instill confidence to visitors and all indicators significantly shape the latent variables with reference to $\mathrm{p}$ value less than 0.05 .

In the confirmatory factor analysis shows that the largest contribution to the variable empathy that Em5 which $71 \%$ related to the facilities where Em5 is about children play ground safely and comfortable. Significance test results also show that the value of each indicator value $p$ value less than 0.05 so that all significant indicators can form latent variable dimensions of service quality of empathy.

While the largest contribution to the variable responsiveness that RS2 which amounted to $88 \%$ where RS2 associated with travel personnel having a good 
responsiveness in handling requests visitor wherein each indicator also form a responsiveness latent variable.

Furthermore, the ServQual variable based on the CFA analysis shows that the largest contribution to the satisfaction variables is KP4 which amounted to $91 \%$ where KP4 associated with visitors would recommend others to visit the Blitar kakao agrotourism.

Quality of service is one of the fundamental management strategies to gain visitor satisfaction. In the face of competition, the managers need to be able to compete with improving the service quality so would encourage the achievement of visitor satisfaction. It certainly would be a positive influence on the image of the Blitar kakao agrotourism. Visitors are satisfied with the services quality will position it as a primary detinastion when compared to other agro-tourism offered in the area of Blitar.

Based on the structural analysis indicate that the hypothesis proposed in this study can be accepted, which means that the quality of services significantly give positive effect on visitor satisfaction.

Based on the standardized regression weights show the estimate value for the variable effect on visitor satisfaction ServQual of 0.88 , while the results obtained regression weights SE values of 0.128 , CR of 9.261. From the analysis also show that the $\mathrm{p}$ value for the link between the quality of service (ServQual) with visitor satisfaction $<0.05$ so that it can be concluded that service quality significantly influence visitor satisfaction.

The high quality value of service will have a positive impact on visitor satisfaction. From a structural method can also be known which indicators most influence on the quality of service which is based on the analysis we found that the reliability dimension has the most impact on the four other dimensions. In addition, the indicators most influence on satisfaction is the quality of services provided as promised.

The vision of Blitar kakao agrotourism is to educate the tourist and to be a primary destination still need improvement on the dimensions of responsiveness. It evident from the results of the analysis shows that the responsiveness service quality indicators consisting of interaction and attention from management towards visitors still considered less in the forming of visitor satisfaction. This may indicate that cocoa agro still less than optimal in human resource development to its employees. Regular internal meetings and training related technical good service needs to be done. In addition, the self-development courses in order to improve the working ability according with the concept of service is also important to do.

Blitar kakao agrotourism managers also need to monitor the visitor satisfaction surveys on a regular basis to anticipate changes that may occur in the future. The results of the survey on a regular basis would be a reference for Blitar kakao agrotourism in developing and fostering relationships with visitors, both old tourists or new tourist so that the survey can be used as a basis for policy in implementing strategic management to increase the value of satisfaction.

\section{CONCLUSION}

Based on research results related to analysis of the effect of service quality on visitor satisfaction was concluded as follows.

1. The results showed that the quality of service simultaneously affect the Blitar kakao agrotourism visitor satisfaction. It can be said that if the quality of service is increased, the perceived level of satisfaction will increase too.

2. The analysis also showed that all the indicators used in the variable tangible, responsiveness, empathy, assurance, reliability and customer satisfaction are forming unidimentionality

3. Variables of reliability have the greatest influence on visitor satisfaction when compared with the other dimensions of service quality. If the value of the reliability variable increased while the value of other variables made constant it will significantly influence the visitor satisfaction.

4. ServQual of responsiveness consisting of interaction and attention towards visitors still considered less in the forming of visitor satisfaction. This may indicate that Blitar kakao agrotourism management still less than optimal in human resource development.

The advice given by the results are as follows.

1. Blitar kakao agrotourism manager must be able to improve services at several variables where the visitors have not been get an expected with reference to the assessment of visitor satisfaction. Human resource development strategy can be done to improve the quality of service on responsiveness variable.

2. Fostering human resources through continuous internal meetings. In addition, including in technical training employees such as self-development courses so that the competencies and attitudes of work behavior are in accordance with the concept of excellent quality service.

3. For subsequent researchers, necessary to add or make variables more detail to get better results.

\section{REFERENCES}

[1] R. C. Mill, Tourism: The International Business. London: Prentice Hall, 1990.

[2] P. Kotler and K. L. Keller, Manajemen Pemasaran. Jakarta: Erlangga, 2009.

[3] B. S. Dharmmesta and H. Handoko, Manajemen Pemasaran. Yogyakarta: BPFE Yogyakarta, 2000.

[4] M. Mardiyatmo, Kewirausahaan Untuk Tingkat 1 SMK. Jakarta: Yudistira, 2005.

[5] V. A. Zeithaml, M. J. Bitner, and D. D. Gremler, Services Marketing: Integrating Customer Focus Across the Firm, 5th ed. New York: McGraw-Hill Irwin, 2009. 
The $1^{\text {st }}$ International Conference on Business and Management of Technology (IConBMT)

August 3rd 2019, Institut Teknologi Sepuluh Nopember, Surabaya, Indonesia

[6] Parasuraman, V. A. Zeithaml, and L. L. Berry, "SERVQUAL: a multiple-item scale for measuring consumer perceptions of service quality,” J. Retail., vol. 64, no. 1, pp. 12-40, 1988.

[7] F. Tjiptono, Strategi Pemasaran. Yogyakarta: Andi Offset, 2007.
[8] Sugiyono, Metode Penelitian Pendidikan: Pendekatan Kuantitatif, Kualitatif dan R\&D. Bandung: Alfabeta, 2006.

[9] A. T. Basuki, Analisis Regresi dengan SPSS. Yogyakarta: Katalog Dalam Terbitan (KDT), 2015. 